\title{
WHO ARE WE TRYING TO PROTECT? THE ROLE OF VULNERABILITY ANALYSIS IN NEW ZEALAND'S LAW OF NEGLIGENCE
}

\author{
Scott William Hugh Fletcher*
}

New Zealand has incorporated ideas of vulnerability within its law of negligence for some years. It has not, however, clarified what is meant by vulnerability or the role the concept plays within the broader duty of care framework. Several obiter comments in Body Corporate No $207624 \mathrm{v}$ North Shore City Council (Spencer on Byron) suggest the concept ought not to be part of the law due to its uncertain and confusing nature. Subsequent cases have, however, continued to use the concept, and continue to use it despite both its historically ill-defined nature and the additional uncertainty added by Spencer on Byron. This article argues that vulnerability can and ought to be a part of New Zealand negligence law. With a consistent application of a single test for vulnerability - that established in the High Court of Australia in Woolcock Street Investments Pty Ltd v CDG Pty Ltd - vulnerability can be conceptually certain and provide useful insight into the issues posed by the law of negligence.

\section{INTRODUCTION}

"[V]ulnerability is a poorly understood concept". ${ }^{1}$ It can refer to a wide range of ideas and play a part in a wide variety of legal arenas. In Body Corporate No 207624 v North Shore City Council (Spencer on Byron), three judges of the Supreme Court made obiter suggestions that vulnerability should have a limited role to play in New Zealand negligence law. ${ }^{2}$ Despite these observations, the concept was extensively used in the recent case of Carter Holt Harvey Ltd v Minister of Education

* Submitted as part of the LLB(Hons) programme at Victoria University of Wellington. Awarded the Robert Orr McGechan Memorial Prize for the Best Student Work for the Victoria University of Wellington Law Review. I am extremely grateful for the passionate support and guidance provided by my supervisor, Professor Bill Atkin, and to the many friends and colleagues who patiently looked over my many drafts.

1 Seales v Attorney-General [2015] NZHC 1239, [2015] 3 NZLR 556 at [77].

2 Body Corporate No 207624 v North Shore City Council [2012] NZSC 83, [2013] 2 NZLR 297 [Spencer on Byron] at [38] per Tipping J and at [156] per Chambers and McGrath JJ. 
(Carter Holt (CA)) and in such a way that the decision effectively turned on the application of the concept. ${ }^{3}$ This leaves the law of negligence in a regrettable state of flux and, given that "issues of vulnerability are apt to be problematic", clarification of the role of vulnerability in negligence law is needed. ${ }^{4}$

This article argues that, contrary to the suggestions in Spencer on Byron, vulnerability can be a concept that is "capable of reasonably clear and consistent administration". 5 To that end, it suggests the courts adopt the test for vulnerability taken by the High Court of Australia in Woolcock Street Investments Pty Ltd v CDG Pty Ltd (Woolcock): that the court assess vulnerability based on whether the plaintiff had reasonable alternative means to protect themselves. ${ }^{6}$ Through simple and consistent adoption of that test, many of the issues that confuse vulnerability can be addressed, and it is suggested that this provides a clear focus for an analysis of vulnerability.

The article has three substantive parts. Part II discusses the Carter Holt case, summarising how the concept of vulnerability was used within the Court's approach to the duty of care issue. This provides an introduction to the concept, highlighting several of its analytical strengths and weaknesses. Part III expands upon the meaning of vulnerability, discussing how the concept is used in a variety of situations before settling on the Australian test from Woolcock. It will be seen that vulnerability is used in a variety of different ways by different sources, and that it is necessary to have one single approach within the law of negligence to achieve conceptual clarity. Finally Part IV discusses how the Woolcock test can fit within the broader law of negligence, suggesting ways in which it works alongside other areas within the duty of care analysis. Several criticisms of vulnerability are addressed, and it is suggested that there is a tendency to overstate the extent to which the concept is confusing.

\section{THE CARTER HOLT CASE}

\section{A The Judgment}

The Carter Holt decision appears to be the first case to feature an analysis of vulnerability after the observations in Spencer on Byron. This summary focuses on the negligence cause of action, and especially on the reliance on an analysis of vulnerability within that cause of action. Vulnerability was

3 Carter Holt Harvey Ltd v Minister of Education [2015] NZCA 321, (2015) 14 TCLR 106 [Carter Holt (CA)]. The Supreme Court granted leave to appeal the Court of Appeal's judgment: Carter Holt Harvey Ltd v Minister of Education [2015] NZSC 182.

4 Spencer on Byron, above n 2, at [38] per Tipping J.

5 North Shore City Council v Body Corporate 188529 [2010] NZSC 158, [2011] 2 NZLR 289 as cited in Spencer on Byron, above n 2, at [156] per Chambers and McGrath JJ.

6 Woolcock Street Investments Pty Ltd v CDG Pty Ltd [2004] HCA 16, (2004) 216 CLR 515 [Woolcock] at [23] per Gleeson CJ, Gummow, Hayne and Heydon JJ. 
heavily utilised in both the High Court and the Court of Appeal, but its application to the facts of the case was not well reasoned. ${ }^{7}$

The plaintiffs were the Minister of Education and the Boards of various Schools around the country which owned or administered leaky buildings. They sued various manufacturers who had provided sheet cladding systems for the buildings, alleging the materials were inherently defective. Carter Holt was the only defendant not to settle the claims against it, and applied to have the claims struck out.

The plaintiffs claimed Carter Holt owed them a duty of care in negligence to "design, manufacture and supply cladding sheets for use on the school buildings that complied with Recognised Building Standards, the Building Code requirements and the Building Acts". ${ }^{8}$ The sheets at issue were called Shadowclad, a form of plywood cladding used in the construction of the school buildings. The plaintiffs claimed that Shadowclad allowed unacceptable levels of moisture ingress into the building, resulting in structural damage, rot and a loss of value in the plaintiffs' properties. The case has conceptual similarities with other "leaky building" cases that have been before the courts for some 15 years, with concerns about occupant health and the structural integrity of the plaintiffs' buildings a major part of the claimed loss. ${ }^{9}$

In response Carter Holt argued that it could not owe the plaintiffs a duty of care. It was not in a sufficiently proximate relationship with the plaintiffs, both because of the way "building work" was defined in relevant legislation and because of the contractual nexus between the parties. ${ }^{10}$ The plaintiffs also sued under the Consumer Guarantees Act 1993, the tort of negligent misstatement, an allegation of a negligent failure to warn and the Fair Trading Act 1986. In the High Court, Carter Holt failed to strike out any of the plaintiffs' causes of action. On appeal, the Court of Appeal struck out the negligent misstatement claim, but all other claims were allowed to proceed to trial. This summary does not further consider these causes of action and, similarly, limitation defences pleaded by Carter Holt are not considered.

The Court of Appeal held it was arguable that Carter Holt owed the plaintiffs a duty of care in negligence. It applied the two-step framework from South Pacific Manufacturing Co Ltd v New Zealand Security Consultants \& Investigations Ltd (South Pacific), assessing whether the parties were

7 Minister of Education v Carter Holt Harvey Ltd [2014] NZHC 681 [Carter Holt (HC)]. The High Court's reasoning on the negligence cause of action is affirmed by the Court of Appeal: Carter Holt (CA), above n 3 , at [99]-[100].

8 Carter Holt (CA), above n 3, at [5].

9 At [84]-[96].

10 At [27]-[32]. 
in a proximate relationship such that it was foreseeable that Carter Holt's allegedly negligent conduct could cause the plaintiffs loss, and then whether policy factors negated that prima facie duty of care. ${ }^{11}$

Foreseeability of loss was clearly established on the facts as pleaded by the plaintiffs. ${ }^{12}$ As its manufacturer, Carter Holt could reasonably have foreseen Shadowclad being used in buildings and that, if it leaked, the buildings could suffer damage. The question of proximity between the parties was more finely balanced. The Court considered three key arguments: whether the Building Acts and Building Code supported the alleged duty, whether the contractual matrix surrounding the parties' relationship told against the existence of the alleged duty, and whether the plaintiffs were vulnerable. The latter two points are the focus of this part and they illustrate important ideas about the place of vulnerability in New Zealand law.

Neither the relevant statutory framework nor the relevant contractual matrix prevented the recognition of the claimed duty of care. The statutory framework of the Building Acts and Building Code regulated "building work", but building work (at the time the plaintiffs' buildings were constructed) did not include the manufacturing of components like Shadowclad. The Court did not view this silence as decisive, suggesting the factual relationship between the parties was the overriding concern. ${ }^{13}$ Similarly, the contractual matrix did not necessarily prevent the Court recognising the claimed duty of care. ${ }^{14}$ The Court referred to several cases discussing the effect of contractual relationships on the existence of tortious duties of care, including the leading case of Rolls-Royce New Zealand Ltd v Carter Holt Harvey Ltd (Rolls Royce). ${ }^{15}$ The contractual matrix at issue in this case was "readily distinguishable" from that featured in Rolls Royce, being "diffuse and decentralised", and the limited facts before the Court suggested different policy issues to those salient in that case. ${ }^{16}$ Suggestions raised by Carter Holt that the plaintiffs could have contractually allocated risk, and the possibility of their doing so, were better left to trial when all the evidence was before the Court. ${ }^{17}$

Further, the existence of the claimed duty was supported by the vulnerability of the plaintiffs. Regrettably the analysis as to the vulnerability of the plaintiffs diverges between the High Court and the Court of Appeal, despite the Court of Appeal endorsing the approach taken by the High Court. ${ }^{18}$

11 South Pacific Manufacturing Co Ltd v New Zealand Security Consultants \& Investigations Ltd [1992] 2 NZLR 282 (CA) [South Pacific] at 305 per Richardson J.

12 Carter Holt (CA), above n 3, at [42]-[43].

13 At [68].

14 At [52].

15 Rolls-Royce New Zealand Ltd v Carter Holt Harvey Ltd [2005] 1 NZLR 324 (CA) [Rolls Royce].

16 Carter Holt (CA), above n 3, at [56]-[58].

17 At [60].

18 At [74]. 
In the High Court, Asher $\mathbf{J}$ cited the Woolcock case and stated three different ways in which the plaintiffs were vulnerable vis-à-vis the defendants, two of which are clear applications of the Woolcock test. ${ }^{19}$ The Court of Appeal, however, stated that the Woolcock test was not good law in New Zealand and refused to consider notions of contractual self-protection as relevant to the vulnerability analysis, whilst stating no ways in which the plaintiffs were vulnerable in its own judgment. ${ }^{20}$ The unfortunate contradictions between these two judgments are discussed at length below. Both judgments agreed that the plaintiffs were vulnerable however, and that overall the claim could proceed to trial despite being "finely balanced" on the proximity point. ${ }^{21}$

The Court of Appeal further considered that the policy factors at play in the case were not sufficient to negate the resulting prima facie duty of care. ${ }^{22}$ Relevant policy factors included that the moisture ingress affecting the buildings in turn affected occupants' health, which weighed in favour of a duty of care. ${ }^{23}$ There was also some suggestion that manufacturers in the position of Carter Holt would bear an unfair proportion of responsibility for leaky buildings, but that was balanced by the public benefits obtained from promoting "the careful development and testing of products, and accurate marketing as to their qualities" ${ }^{24}$ Considerations of commercial certainty may have further weighed against a duty of care, but the Court preferred those to be left to trial where evidence could establish the exact extent of their relevance. ${ }^{25}$ Finally, the duty argued for would not conflict with other areas of law and might in fact be supported by various public law duties acting upon the parties. $^{26}$

On that basis, the Court was not prepared to strike out the claim alleged by the plaintiffs in negligence. The importance of the vulnerability analysis cannot be overstated; it is the only positive factor at the proximity stage supporting the claimed duty of care. It is unfortunate then that the analysis on the vulnerability point is so conflicted, and it is suggested that the judgment cannot be properly understood without a careful examination of that analysis.

19 Carter Holt (HC), above n 7, at [46].

20 Carter Holt (CA), above n 3, at [74].

21 Carter Holt (HC), above n 7, at [49]; and Carter Holt (CA), above n 3, at [76].

22 Carter Holt (CA), above n 3, at [100].

23 At [96].

24 Carter Holt (HC), above n 7, at [59].

25 Carter Holt (CA), above n 3, at [80].

26 At [98] 


\section{$B$ Critiquing the Vulnerability Analysis}

In the High Court, there were three points affecting the plaintiffs' vulnerability: first, that the plaintiffs could not detect the latent defects that caused them loss; secondly, that the degree of separation between the parties and the multiplicity of components suggested the plaintiffs could not be expected to take steps to protect themselves; and thirdly, that the plaintiffs may have had the ability to take steps to obtain contractual warranties or insurance. ${ }^{27}$

The first point suggests that a party cannot be expected to protect itself if it does not know it needs to do so. As the defects in Shadowclad were not likely to have been apparent, the plaintiffs could not have hired experts to investigate the building for defects as they would not have known they needed to do so. ${ }^{28}$ In this respect, the observation in Woolcock that there was no suggestion in that case the alleged defects "could not have been discovered"29 strongly indicates that the Judge was utilising the test from that case. A party is potentially not vulnerable if it is at least capable of discovering a loss because it is able to potentially know of the need to take steps to protect against it; conversely, a party who is incapable of discovering a loss cannot know of that need.

The second and third points relate to the opportunities afforded to the plaintiffs in contract. The third point acknowledges the potential ability of the plaintiffs to obtain contractual warranties, the exact analysis rejected by the Court of Appeal. The second point reflects earlier observations by the Judge within the contractual matrix section of the analysis that there was no evidence as to the extent "warranties were obtained commonly by owners in the industry in this context, or whether indeed it would have been at all practical to insist on such warranties". ${ }^{30}$ As with the first point above, this analysis appears to relate to observations in Woolcock as to how vulnerability applied to the facts of that case. The plaintiff in Woolcock was a subsequent purchaser of a warehouse, and the original owner had not obtained contractual warranties from the builder or assigned his rights against third parties involved in the construction of the warehouse to the subsequent purchaser. ${ }^{31}$ The majority stated that on those facts the plaintiff could have availed himself of protection in contract, but did not, and accordingly was not vulnerable. ${ }^{32}$ If that logic is applied to the facts of this case, it is suggested that Asher J's emphasis on the lack of evidence as to the practicality of obtaining similar contractual

27 Carter Holt (HC), above n 7, at [46].

28 At [46].

29 Woolcock, above n 6, at [23] per Gleeson CJ, Gummow, Hayne and Heydon JJ.

30 Carter Holt (HC), above n 7, at [41].

31 Woolcock, above n 6, at [31] per Gleeson CJ, Gummow, Hayne and Heydon JJ.

32 At [31]. 
protections reflects concerns that arguably the plaintiffs in this case could not have taken steps to protect themselves in contract. ${ }^{33}$

If that is accepted, then the second and third points are in essence simply a single factor addressing the viability of contractual protections. In the High Court, the absence of evidence protected the claim from strike out because the judge could not be sure whether the means of contractual self-protection were reasonable in the circumstances (and by extension whether the plaintiffs were vulnerable). If Carter Holt could lead evidence suggesting the costs of obtaining contractual warranties were low, or that insurance was reasonably available, the Court would not have considered the plaintiffs to be vulnerable at trial. In that sense then, the High Court was concerned by the practical possibility of the plaintiffs obtaining means to protect themselves. An obvious means of obtaining such protection is through the law of contract, and it is for this reason that the High Court judgment frames issues of vulnerability alongside analysis of the contractual matrix at issue in the case.

The implicit relationship between the contractual matrix analysis and the vulnerability analysis just described is an important one, and its significance is discussed at some length in Part IV. For present purposes however it must be emphasised that the Court of Appeal's rejection of Woolcock vulnerability is illogical and renders the judgment critically flawed. Indeed, if its rejection of the Woolcock test is correct, there would be no reason to consider the plaintiffs vulnerable as the analysis at first instance was dependent on that test. By extension, since the vulnerability analysis was the only positive factor supporting a finding of proximity, the Court of Appeal must have been in error in not striking out the claimed duty of care. The Court cited no authority for its suggestion that contractual self-protection was not a part of an analysis of vulnerability, other than the points of obiter from Spencer on Byron mentioned above (comments which reject vulnerability analysis). ${ }^{34}$ Further, the analysis that the Court rejected - ascertaining the reasonableness of contractual warranties - is undertaken by the same Court earlier in its judgment as part of its analysis as to the contractual matrix existing between the parties. ${ }^{35}$ Finally, the Court of Appeal's own statement of the test in the High Court, whether the plaintiffs "could have been expected to know of, and take steps to protect itself against, the risks in shadowclad" is exactly the same approach as in Woolcock, for it focuses on the self-protective means available for the loss at issue. ${ }^{36}$ It is thus difficult to understand on what basis the Court of Appeal took the view it did.

An analysis of vulnerability played a major part in the Carter Holt decision. It is suggested that the High Court's approach to vulnerability is correct and allows for a logically consistent and

33 Carter Holt (HC), above n 7, at [47].

34 Spencer on Byron, above n 2, at [38] per Tipping J and at [156] per Chambers and McGrath JJ.

35 Carter Holt (CA), above n 3, at [60].

36 At [74]. 
conceptually clear judgment. Neither Court examined the reasons for the plaintiffs' vulnerability in detail. Nonetheless, the idea of "practical" self-protection that found favour in the High Court (and to an extent in the Court of Appeal) is a helpful introduction to the concept.

\section{UNDERSTANDING VULNERABILITY}

\section{A Vulnerability Generally}

The High Court has suggested a test for vulnerability in the negligence context: that set down by the High Court of Australia in Woolcock. To understand why such a specific test for vulnerability is necessary, it is helpful to explore what the concept means generally and how it has been used by the courts. This part first seeks to suggest why vulnerability risks being conceptually confusing, identifying the source of the problems raised by Spencer on Byron. It then discusses how New Zealand case law has defined vulnerability in the negligence context, noting an unfortunate tendency to complicate the concept. Finally, it discusses what the test for vulnerability ought to be in New Zealand, seeking to resolve that confusion by critiquing some of the various approaches suggested in the cases.

A person may or may not be vulnerable depending on the context. This is well illustrated by the recent decision of Seales $v$ Attorney-General. ${ }^{37}$ In that case, the plaintiff sought declarations allowing her to end her own life and protecting her doctor from criminal liability if her doctor assisted her to do so. Significant argument focused on the potential vulnerability of persons seeking euthanasia, and the evidence led by the Attorney-General noted a vast range of differing circumstances where someone could be considered vulnerable, including medical, ethical and social circumstances. In keeping with that broad approach to vulnerability, Fineman suggests that a notion of vulnerability might be a basis for an alternative ethical foundation for our political system, discussing the extent to which humans are universally vulnerable vis-à-vis each other. ${ }^{38}$ In a narrower fashion, vulnerability has been said to be the "golden thread" that underpins such diverse areas of law as breach of fiduciary duty, undue influence, unconscionability and negligent misrepresentation. ${ }^{39}$ Similarly, Stapleton suggests significant aspects of the law of negligence - such as reliance and reasonable foreseeability - can be explained using notions of vulnerability, ${ }^{40}$ an argument that attracted judicial support in Woolcock. ${ }^{41}$

37 Seales v Attorney-General, above n 1, at [77].

38 Martha Albertson Fineman "Equality, Autonomy and the Vulnerable Subject in Law and Politics" in Martha Albertson Fineman and Anna Grear (eds) Vulnerability: Reflections on a New Ethical Foundation for Law and Politics (Ashgate, Surrey, 2013) 13 at 13.

39 Hodgkinson v Simms [1994] 3 SCR 377 (SCC) at [25].

40 Jane Stapleton "Comparative Economic Loss: Lessons from Case-Law-Focused 'Middle Theory'" (2002) 50 UCLA L Rev 531 at 558-559.

41 Woolcock, above n 6, at [24] per Gleeson CJ, Gummow, Hayne and Heydon JJ. 
Any or all of the different approaches to vulnerability may be correct within their different contexts. For current purposes though, what these arguments illustrate is the breadth of ways in which vulnerability can be used. If vulnerability is to be used by the courts in the duty of care analysis, there needs to be a clear test that ensures conceptual clarity and avoids the uncertainty that attaches to such a broad concept. As Todd puts it, "[f]or a principle of vulnerability to work properly, we need to be able to point to a category of claim where plaintiffs can be treated as vulnerable". ${ }^{42}$ If claimants are unsure when they are vulnerable in the sense used by a case, unacceptable uncertainty results.

\section{B Vulnerability in New Zealand Case Law}

It follows from that conclusion that, if vulnerability has caused conceptual confusion in the past, it is likely because the courts have not adopted a straightforward approach to the concept. In New Zealand, several leading judgments have discussed notions of vulnerability, but their usage of the concept is unfortunately inconsistent. The logical place to begin a discussion of vulnerability in negligence is the well-known distinction between residential and commercial building owners that existed pre-Spencer on Byron. In two cases the Court of Appeal stated commercial owners of buildings could not sue for damage to their buildings caused by negligent building work because they "cannot be characterised as 'vulnerable' in the same way as house-owners". ${ }^{43}$ In Te Mata Properties Ltd v Hastings District Council (Te Mata) Baragwanath J suggested that the distinction was due to the "public interest in secure habitation" and "presumed economic vulnerability". ${ }^{44} \mathrm{He}$ considered that, given the claim for a defective building was primarily one of economic loss, it ought to be confined to situations where there was a risk to individual health and where the plaintiff was resident in the dwelling.

As the majority in Spencer on Byron pointed out, however, that analysis is based on assumptions about the position of commercial and residential owners that cannot be correct. ${ }^{45}$ There are many conceivable situations where a commercial owner could be in a worse economic position than a residential owner, and the health justification can easily and conceivably apply to premises used commercially. ${ }^{46}$ It similarly cannot be assumed that commercial owners can always protect their own interests, for in some circumstances there may be structural market reasons why forms of self-

42 Stephen Todd "Policy Issues in Defective Property Cases" in Erika Chamberlain, Jason Neyers and Stephen Pitel (eds) Emerging Issues in Tort Law (Hart, Oxford, 2007) 199 at 228 (emphasis in original).

43 Queenstown Lakes District Council v Charterhall Trustees Ltd [2009] NZCA 374, [2009] 3 NZLR 786 at [39]; and Te Mata Properties Ltd v Hastings District Council [2008] NZCA 446, [2009] 1 NZLR 460 [Te Mata].

44 Te Mata, above n 43, at [62] and [57].

45 Spencer on Byron, above n 2, at [197] per Chambers and McGrath JJ.

46 At [169] per Chambers and McGrath JJ. 
protection (insurance for example) are not available, a point recognised in the High Court judgment of the Carter Holt case. $^{47}$

For an analysis of vulnerability to work, the position of the allegedly vulnerable party must be examined in detail and against a clear comparator. With respect, it cannot be conducive to effective reasoning for a court to rest a duty of care on a presumption of a plaintiff's circumstances. Each case "should be decided on its merits". ${ }^{4}$ The approach used by Baragwanath J relied on arguable interpretations of various statutes and lacked analysis of the plaintiff's means or opportunities, and such an approach unsurprisingly led to uncertainty. On a simpler level, the distinction drawn by the Court of Appeal was prone to significant conceptual difficulties at the margins, with cases involving short-term accommodation and school buildings both causing later courts difficulty. Indeed, Todd suggests that this lack of conceptual clarity is a primary reason why the Court in Spencer on Byron rejected the distinction. ${ }^{49}$ If vulnerability analysis is to be undertaken by the courts, it needs to have a greater degree of conceptual clarity than the analysis in Te Mata.

It is perhaps understandable then why the Court in Spencer on Byron cast doubt on the use of vulnerability in negligence law. However, there are other judgments of high authority that use the concept in more helpful ways. In South Pacific a fire had destroyed the buildings of an insured party in two separate claims before the Court. ${ }^{50}$ In one claim, the insured alleged that the investigator had negligently conveyed to the insurer that the insured were responsible for the fire, and as a result the insurer had refused to indemnify the insured for their loss. Though the claim failed, Hardie Boys $\mathbf{J}$ noted: ${ }^{51}$

The factor most strongly favouring recognition of a duty of care in the present case is what might be called the vulnerability of the insured ... the insured is unlikely to call in an investigator of his own, certainly not until it is probably too late.

Richardson $\mathbf{J}$ similarly commented that the plaintiffs had "no obvious means of protecting themselves against the risk of carelessness on [the investigator's] part in other aspects of the investigation and reporting" and that "a plaintiff who has had the opportunity ... [in] contract to obtain

47 Carter Holt (HC), above n 7, at [47].

48 Rosemary Tobin "Leaky Buildings and the Local Authority: The Tortious Solution and the Hamlin Conundrum" (2011) 17 NZBLQ 346 at 361

49 Stephen Todd and others The Law of Torts in New Zealand (6th ed, Thomson Reuters, Wellington, 2013) at 165.

50 South Pacific, above n 11.

51 At 317-318 per Hardie Boys J. 
full contractual protection against this kind of loss cannot expect society to provide further protection through tort law". 52

In essence, the judgments analyse the capacity of plaintiffs to protect themselves from the loss, which is the same approach utilised by Asher $\mathrm{J}$ in the Carter Holt case.

The decision in Rolls Royce goes further and expressly states a test for vulnerability. ${ }^{53}$ In that case, the plaintiff, Carter Holt, entered into a contract with the Electricity Corporation of New Zealand (ECNZ) for the construction of a generator. ECNZ subcontracted with Rolls Royce, but Carter Holt chose not to contract with Rolls Royce itself. Glazebrook J held that "[t]he strongest factor pointing away from a proximity finding is the very contractual structure that made loss to Carter Holt foreseeable". ${ }^{54}$ Carter Holt had the opportunity to protect itself in contract, but had chosen not to, and was a "sophisticated commercial part[y]" which had made that decision freely. ${ }^{55}$ It is suggested that a finding that a party is "sophisticated" and "commercial" is inherently finding they are not vulnerable, and the Judge notes vulnerability is a "key factor" in the duty of care analysis. ${ }^{56}$ Two tests for vulnerability are mentioned: whether a defendant with special skills has power over a vulnerable plaintiff, and whether there were reasonable alternative means of protection available to the plaintiff. ${ }^{57}$

The latter category is the same as that used in Woolcock, and that judgment is cited in support of the test. It is not entirely clear from the first category of vulnerability however what factors will make the plaintiff vulnerable such that the defendant's special skills are relevant (or alternatively whether it is the defendant's special skills that make the plaintiff vulnerable). With respect, it is not helpful to state a test that requires a court already know the plaintiff is vulnerable. If the test is not to create confusion, it must operate in a way that ensures analytically sound results.

The final leading authority is Minister of Education v Econicorp Holdings Ltd (Econicorp). ${ }^{58}$ In that case, the appellant was the owner of several school buildings affected by moisture ingress, allegedly due to negligent construction by the respondent. The School's Board of Trustees was party to the contract with the defendant, but the Minister was not, as this reflected the Government's policy on the Minister's relationship with school boards. The majority refused to strike out the Minister's claim in tort despite acknowledging both that the Minister was not vulnerable and that the contractual

52 At 307 and 309 per Richardson J.

53 Rolls Royce, above n 15.

54 At [103].

55 At [104].

56 At [61] citing Woolcock, above n 6.

57 At [61]-[62].

58 Minister of Education v Econicorp Holdings Ltd [2011] NZCA 450, [2012] 1 NZLR 36 [Econicorp]. 
nexus told against the imposition of a duty of care. The Minister was a "sophisticated, well-resourced party" who had made a deliberate decision not to contract with the defendant (reflecting Government policy) and the contract itself had provisions that suggested the Board had itself obtained the kind of contractual protections the Minister could have chosen to obtain. ${ }^{59}$ The majority nonetheless considered that the situation was "not a truly commercial" one, and that the public law relationship between the Minister and the Board suggested there were other reasons for the Minister not contracting with the defendant. ${ }^{60}$

With respect, a plaintiff's subjective reasons for not availing themselves of self-protection ought to be irrelevant. ${ }^{61}$ Whether under the guise of vulnerability or other areas of duty analysis, a court ought not to recognise a duty of care where a plaintiff deliberately chose to forgo "full protection" outside of negligence. ${ }^{62}$ Further, the concept of vulnerability is likely to be significantly complicated by the addition of such subjective elements into a court's analysis, requiring as they do additional evidence and creating further uncertainty within otherwise well-defined relationships.

\section{The Appropriate Test for Vulnerability}

Following these decisions then, there is some doubt both as to the existence of a test for vulnerability in negligence law and what form that test might take. It is suggested that New Zealand law ought to adopt the Woolcock test without any of the additional complicating factors noted above - essentially the way it was utilised in the High Court judgment of the Carter Holt case. To repeat, that test asks whether there were reasonable opportunities available to the plaintiff for self-protection from harm caused by the defendant's want of reasonable care. ${ }^{63}$ The aim of the concept is to allow negligence to fill holes in areas where pre-existing legal protections are insufficient, for if such protections already exist plaintiffs will have had a reasonable opportunity to protect themselves. ${ }^{64}$ This is a straightforward and clear concept well utilised in Australian jurisprudence, and it is conceptually clear once complicating factors from some of the New Zealand cases are removed.

Absent from that test are the complicating factors identified in the cases discussed above. The insistence on a deliberate examination of the opportunities available to the plaintiff precludes a presumption of vulnerability. The difficulties with making such a presumption are numerous. First, as the Te Mata distinction illustrated, there are likely to be examples of cases that rebut the

59 At [45]-[46].

60 At [61].

61 At [81] per Harrison J (dissenting).

62 At [89] per Harrison J (dissenting); and South Pacific, above n 11, at 310 per Richardson J.

63 Woolcock, above n 6, at [23] per Gleeson CJ, Gummow, Hayne and Heydon JJ.

64 Jane Stapleton "The golden thread at the heart of tort law: Protection of the vulnerable" (2003) 24 Aust Bar Rev 135 at 142. 
presumption and which render the rule conceptually unsound. Secondly, the duty of care analysis is usually intensely fact-specific and necessarily relies strongly on the evidence before the court. ${ }^{65} \mathrm{~A}$ presumption is not a substitution for evidence, and presumptions are likely to obscure and confuse the evidence that forms a part of that analysis. Further, since vulnerability is linked to broader concerns around market structures, the court ought to have a sound evidential basis before making a decision that affects the range of stakeholders represented by those concerns. ${ }^{66}$ Finally, a full range of evidence is needed to properly understand the opportunities reasonably available to the plaintiff, and it is likely this reason why the Court in Carter Holt refused to strike out the claimed duty of care. ${ }^{67}$ In Australia, clear evidence is needed before a finding of vulnerability is made. ${ }^{68}$ There is no reason New Zealand should differ, and a presumption of vulnerability contradicts the needs and purposes of the duty of care.

These considerations also suggest the first type of vulnerability in Rolls Royce ought not to be used. ${ }^{69}$ As noted, on the face of it, it is not clear how a plaintiff is deemed "vulnerable" such that the defendant's special skills become relevant. It may be that the plaintiff is vulnerable because of the defendant's special skills, but if that is so then the claim could just as easily be made under the Woolcock test - it would be unreasonable to expect a plaintiff to be aware of opportunities for selfprotection that relied on specialist skills or knowledge the plaintiff lacked. ${ }^{70}$ Beyond being analytically unnecessary, such an approach also utilises ideas of reliance that are more properly part of the law of negligent misstatement. ${ }^{71}$ Perhaps the first test could revolve around particular circumstances of the plaintiff, in a way that is conceptually similar to the equitable doctrines of unconscionable bargain or undue influence. If so, it risks making any resulting duty of care unworkably fact-specific "and impossible to administer" because it risks drawing too much on the specific circumstances of the case before the court. ${ }^{72}$

To be sure, there are some situations where a given plaintiff's vulnerability is obvious. In child abuse cases, for example, the plaintiff's vulnerability cannot be doubted. ${ }^{73}$ However, forcing such

65 Couch v Attorney-General [2008] NZSC 45, [2008] 3 NZLR 725 at [53] per Elias CJ [Couch No 1]; and Christian Witting "Tort Law, Policy and the High Court of Australia" (2007) 31 MULR 569 at 570.

66 Todd and others, above n 49, at 164.

67 Carter Holt (CA), above n 3, at [60].

68 Barclay v Penberthy [2012] HCA 40, (2012) 246 CLR 258 at [87] per Heydon J.

69 Rolls Royce, above n 15, at [61]-[62].

70 Stapleton, above n 40, at 558-559.

71 Spencer on Byron, above n 2, at [199] per Chambers and McGrath JJ.

72 Todd and others, above n 49, at 165.

73 Attorney-General v Prince and Gardner [1998] 1 NZLR 262 (CA) at 282 per Richardson P. 
cases to go through an analytical framework is crucial if any resulting duty of care is to demonstrate the category of claims to which it applies rather than leaving doubts about the boundaries of the duty. Further, the danger of not doing so is that it essentially rests the duty on intuitive ideas about the plaintiff. In the child abuse example, no person would doubt (intuitively or analytically) that the plaintiff deserves protection. In other cases however reasonable people may differ as to whether a particular plaintiff is intuitively vulnerable, and indeed intuitions of vulnerability may not reflect the deeper reality of the situation. It is, for example, difficult to conceive of the Crown as a vulnerable entity. Yet the Minister of Education was a plaintiff in the Carter Holt case, and that decision rejects any intuition of vulnerability in favour of a more nuanced consideration of the particular opportunities and market structures at play in that case. ${ }^{74}$

Similarly, the addition of subjectivity into an analysis of vulnerability adds further uncertainty to the inquiry. A plaintiff's subjective reasons for not utilising self-protective measures may be relevant insomuch as they support a judicial finding that, on the evidence, the plaintiff made a deliberate decision not to exercise the options available to them. Such a finding was made in Rolls Royce ${ }^{75}$ and a similar approach has been utilised in Australian applications of the Woolcock test. ${ }^{76}$

However, to allow a plaintiff's subjective reasons to affect the legal analysis cuts across the certainty that is a key part of commercial relationships and the law of contract (by which many opportunities for self-protection are governed). ${ }^{77}$ A party ought to be able to assume it owes no liability to another party who, knowing it is at risk of injury by actions of the potential injurer and being able to protect itself from those risks, chooses not to do so. Indeed, this is even more so in situations where the party chooses to contract but does not do so on terms that provide that protection. ${ }^{78}$ It is an unfair burden to expect the potential injurer to ascertain why the knowing party chooses not to do so, and in some circumstances it may not be possible for the potential injurer to discharge that burden. In many instances the practical effect of this is that the ability of the plaintiff to obtain insurance becomes relevant. The relationship between insurance and vulnerability analysis is complex, and it may be that there are additional issues that affect vulnerability analysis when insurance becomes relevant. ${ }^{79}$ Such issues are outside the scope of this article. In any event, the addition of subjectivity to the analysis only increases any complexity these issues might have.

74 Carter Holt (CA), above n 3, at [60].

75 Rolls Royce, above n 15, at [104].

76 Brookfield Multiplex Ltd v Owners Corporation Strata Plan 61288 [2014] HCA 36, (2014) 254 CLR 185 [Brookfield Multiplex] at [32] per French CJ.

77 Econicorp, above n 58, at [100] per Harrison J (dissenting); and Rolls Royce, above n 15, at [118].

78 Woolcock, above n 6, at [31] per Gleeson CJ, Gummow, Hayne and Heydon JJ.

79 It is for example unclear whether an emphasis on expecting the plaintiff to obtain insurance tacitly casts the burden of bearing the loss on the plaintiff. It is also somewhat unclear whether a plaintiff who chooses to self- 


\section{PLACING VULNERABILITY WITHIN THE BROADER LAW OF NEGLIGENCE}

\section{A Vulnerability as Part of the Duty of Care Framework}

It has been argued that the Australian test of vulnerability established in Woolcock ought to represent the law in New Zealand. This part builds on the foundations of the Woolcock test to explain how an analysis of vulnerability should function within the broader New Zealand approach to novel duties of care. If the test can be conceptually clarified as previously stated, and clearly placed within the existing framework for assessing novel duties of care, it cannot be considered "unworkable" as was suggested in Spencer on Byron. The part begins by placing vulnerability within the two-stage framework long favoured by the New Zealand courts. It then discusses how it intersects with concerns about the "tort-contract" matrix and the relevance of statutes to the delineation of a vulnerable class of claimant.

Vulnerability has been treated by all of the New Zealand authorities previously referred to as a relevant factor to the proximity stage of establishing a novel duty of care. The Australian courts that developed the Woolcock test however have rejected the usage of proximity within their duty of care analysis, instead choosing to take a different approach whereby vulnerability is a "salient feature" in cases featuring pure economic loss. ${ }^{80}$ The approach to questions of novel duties of care is a flexible and evaluative one, with ideas of proximity and policy guiding rather than binding a court. ${ }^{81}$ It might therefore appear unnecessary to consider the role played by vulnerability in the two-stage test, given that different approaches ought to permit of the same outcome. ${ }^{82}$ The Australian approach to vulnerability however links it strongly to notions of pure economic loss, perhaps even making it a requirement for liability in such cases. ${ }^{83}$

In New Zealand notions of pure economic loss do not attract the same level of concern. ${ }^{84}$ Since the New Zealand approach is a flexible one, it appears inconsistent for the courts to treat vulnerability as either limited to cases of economic loss or to make it a prerequisite of a finding of a duty in such cases. Rather, a finding of vulnerability should be simply one factor the court considers in its overall

insure and absorb the risk of loss should be considered vulnerable if there are no means of self-protection available.

80 Sullivan v Moody [2001] HCA 59, (2001) 207 CLR 562 at [50]; and Brookfield Multiplex, above n 76, at [22].

81 South Pacific, above n 11, at 294 per Cooke P.

82 Kit Barker and others The Law of Torts in Australia (5th ed, Oxford University Press, Melbourne, 2012) at 460

83 Brookfield Multiplex, above n 76, at [22]; and Stapleton, above n 64, at 142.

84 Spencer on Byron, above n 2, at [12] per Elias CJ and at [41] per Tipping J. 
judgement of whether to recognise the claimed duty. ${ }^{85}$ Similarly, and despite the observations noted above, an analysis of vulnerability ought not to be limited to situations where considerations of market structure and associated power imbalances are at play. The reasonable opportunities for a plaintiff to obtain protection can be relevant in many of the situations confronted by the law of negligence, and there is no reason to constrain the flexible New Zealand approach in this way either. ${ }^{86}$

Vulnerability can be a part of that test however only if it is consistent with the way that broad test functions. Beever, responding to Stapleton's arguments cited above, argues that vulnerability "is inconsistent with the important role played by reasonable foreseeability in [the] law". ${ }^{87} \mathrm{~A}$ finding that the plaintiff is vulnerable, he argues, is more likely the less foreseeable the loss at issue was, and on that basis vulnerability cuts across the rest of the analysis undertaken at the proximity stage.

Given that foreseeability of loss is a "screening mechanism" that any claim must pass through before it can be established, the alleged incompatibility appears irrelevant; if the loss was not foreseeable then no duty of care arises, no matter how vulnerable the plaintiff. ${ }^{88}$ Regardless, the argument proceeds on a misunderstanding of how vulnerability analysis functions. The question that an analysis of vulnerability asks is whether the plaintiff could take steps to protect themselves, not whether they would have. It is true that, if the loss was unforeseeable, the plaintiff might not have availed themselves of any self-protective measures, but what matters is whether those self-protective measures were reasonably available to the plaintiff. Indeed, if a plaintiff considered a loss was unlikely and decided it was not worth protecting themselves against, then that deliberative process is exactly that which a non-vulnerable plaintiff would exercise. ${ }^{89}$ The two concepts comfortably sit beside each other, and the Carter Holt case illustrates the distinction; it was reasonably foreseeable that negligent manufacture of Shadowclad would cause damage to the plaintiffs' buildings, but the vulnerability analysis centred on whether the plaintiffs could have protected themselves in contract or through insurance from that loss..$^{90}$

\section{B The Relationship between Vulnerability and the Tort-Contract Matrix}

It is helpful then to discuss how an analysis of vulnerability functions alongside other aspects of the duty of care that are dealt with at the proximity stage. Since vulnerability often relates to

85 Woolcock, above n 6, at [94] per McHugh J.

86 Couch No 1, above n 65, at [71] per Elias CJ and at [124] per Tipping J.

87 Allan Beever Rediscovering the Law of Negligence (Hart Publishing, Oxford, 2007) at 195; and compare Jane Stapleton, above n 40, at 558-559.

88 North Shore City Council v Attorney-General [2012] NZSC 49, [2012] 3 NZLR 341 [The Grange] at [157] per Blanchard J.

89 Woolcock, above n 6, at [31]-[32].

90 Carter Holt (CA), above n 3, at [43] and [75]. 
contractual opportunities afforded to a plaintiff, the tort-contract matrix often employed in the duty of care analysis is directly relevant. Rolls Royce is the leading New Zealand authority in this area, and following that case the courts assess the terms of any contract at issue to ascertain whether they limit or exclude liability in tort, including the possibility of terms not agreed to by the parties. ${ }^{91}$ Following the High Court approach from Carter Holt, the synergy between this analysis and vulnerability analysis is straightforward. Rolls Royce considers the theoretical ability of the plaintiff to seek contractual protection, and the vulnerability analysis considers the practical ability of the plaintiff to obtain that same protection, taking into account market realities and relative bargaining power. ${ }^{92}$ If the theoretical alternatives were reasonably available to the plaintiff, then they were not vulnerable and a duty is unlikely to arise. So much is consistent with the approach in Rolls Royce itself. $^{93}$

The role of vulnerability is not therefore limited to a consideration of impractical alternatives, but assesses how reasonable those alternatives were to parties in the position of the plaintiff. ${ }^{94}$ It was stated previously that any test for vulnerability cannot be determined on the basis of circumstances peculiar to the plaintiff; it would not be enough for a plaintiff in a given proceeding to rely on their own lack of means. Rather they would have to argue that people in their position bargaining with others in the defendant's shoes could not reasonably alter the terms of their relationship, even if selfprotection was theoretically possible. An example of such an argument would be where a standard form contract was imposed on people in the plaintiff's position. ${ }^{95}$

Similarly, it might be enough for the plaintiffs in Carter Holt to show that, even if it was possible to insure against the kind of harm suffered in that case, such insurance would have required lengthy and costly negotiations or significant searching effort such that the means of self-protection was not reasonably available in the circumstances. It might be argued that allowing a reasonableness criterion into an assessment of commercial relationships undercuts the commercial certainty and respect for the free market that is a core part of the law. Yet, as Todd notes, vulnerability can be connected to the very concerns of economic efficiency which motivate that core part of the law. ${ }^{96}$ The point illustrated by the hypothetical arguments above is that, in some circumstances, the transaction costs of achieving self-protection through contract or insurance may be too prohibitive for parties to enter into those arrangements even if doing so might be efficient.

91 Rolls Royce, above n 15, at [103]-[114].

92 Carter Holt (HC), above n 7, at [47].

93 Rolls Royce, above n 15, at [104].

94 Todd and others, above n 49, at 164-165.

95 Smith v Eric S Bush [1990] 1 AC 831 (HL) at 843 and 851 per Lord Templeman; and John Burrows, Jeremy Finn and Stephen Todd Law of Contract in New Zealand (4th ed, LexisNexis, Wellington, 2012) at 20.

96 Todd and others, above n 49 , at 164 
It cannot be said then that the reasonableness criterion is a commercially unsound one. Further, it should be noted that commercial parties may also not reasonably be able to gain self-protection. It could be suggested that, following the analysis in Rolls Royce, a sophisticated commercial party is capable of protecting itself in contract, and that an analysis of vulnerability is unnecessary when dealing with such parties. It is doubtful that the case stands for that proposition, as that factor was only one of several mentioned in the judgment telling against the imposition of a duty of care. ${ }^{97}$

In any event the Carter Holt case did not take that approach and it was right not to do so. A distinction needs to be drawn between being able to negotiate favourable terms in contractual negotiations, and being able to negotiate for the availability of a specific term or protection. The Court of Appeal recognised that, no matter how sophisticated the Minister, if a particular form of protection was not offered in New Zealand, then the Minister could be vulnerable. 98 "Any underlying assumption that commercial parties are generically not vulnerable cannot be right." 99 Just as the court ought not to make presumptions about a particular party's vulnerability, the court should not assume that a commercial party is able to negotiate a specific self-protective term simply by virtue of its resources and bargaining power.

\section{Delineating a Class of Vulnerable Plaintiffs}

A further consideration often utilised by the courts is the extent to which any relevant statutes are consistent with the alleged duty. A duty is unlikely to exist where that duty would conflict with the policy in a given statute. ${ }^{100}$ If a statute draws a distinction between different classes of claims, however, it might be arguable that the distinction drawn reflects a belief by Parliament that one class was vulnerable. This approach is reflected in William Young J's dissent in Spencer on Byron, where the Judge emphasised the different treatment of residential owners from commercial owners in several statutes as reflecting an intention by Parliament to treat commercial and residential owners differently. ${ }^{101}$ It may also be that a statute confers duties and obligations on a particular class of defendant, and that within that regulatory framework some parties that interact with the regulated defendant are vulnerable whereas others are not.

In Smith v Eric S Bush the House of Lords held that a valuer owed a duty of care in tort to purchasers who relied on the valuation they provided to a mortgagee of a property, and that the valuer

97 Rolls Royce, above n 15, at [104].

98 Carter Holt (CA), above n 3, at [76].

99 Spencer on Byron, above n 2, at n 56 per Tipping J. See also Woolcock, above n 6, at [168]-[173] per Kirby $\mathrm{J}$ (dissenting).

100 South Pacific, above n 11, at 297-298 per Cooke P.

101 Spencer on Byron, above n 2, at [301]. See also Te Mata, above n 43, at [57]. 
could not rely on an exclusion clause in the contract of valuation. ${ }^{102}$ The mortgagee was not vulnerable as they were able to bargain directly with the valuer as to the terms of their relationship, but a purchaser could not (and might also be of limited means), meaning the latter was vulnerable. ${ }^{103}$ Since the English Parliament had intended to limit the availability of exemption clauses and provide for liability for valuers in some circumstances, it was consistent for the Court to recognise a duty owed to vulnerable purchasers. ${ }^{104}$ Just as Parliament might delineate a vulnerable class, it might also establish a protection regime wherein some classes of people required tortious protection.

There is nothing of principle in that approach that can be objected to, but care must be taken during the statutory interpretation exercise. Since a class is only vulnerable due to the absence of effective pre-existing legal protections, if Parliament was not considering the availability of those protections when passing the relevant statute, it did not necessarily intend to treat the class as vulnerable. The statutory regime in Smith v Eric $S$ Bush was specifically targeted at the ambit of liability for professional valuers, and evidence of Parliament's intent was readily available. ${ }^{105}$ That will not necessarily be true in all cases, however, and as vulnerability can be utilised in a variety of different ways, it cannot be assumed that a delineation of a class by Parliament necessarily reflects the approach to vulnerability the courts ought to be concerned with. It should also be remembered that Parliament may not have intended distinctions drawn between different classes to reflect considerations of liability. Responding to an argument from the defendant's counsel, Chambers and McGrath JJ in Spencer on Byron considered distinctions drawn by the Building Act were not intended to form the basis of the claimed distinction between residential and commercial buildings. ${ }^{106}$ The distinctions were not intended to form the basis of tortious liability, but rather were designed to tailor regulatory requirements to different types of building.

Despite these challenges though, the focus on statutory criteria is helpful insomuch as it reflects a positive emphasis on the clear "line-drawing" necessary to ensure a principled and workable duty of care ${ }^{107}$ If a statutory regime can provide a principled and workable distinction then the courts ought to utilise that distinction, but if not the use of comparator groups may be of some assistance. A comparator group is a mechanism frequently used in the human rights context to assist in cases of alleged discrimination. ${ }^{108}$ In this context, the exercise would involve comparing those within the

102 Smith v Eric S Bush, above n 95.

103 At 851 per Lord Templeman.

104 At 857 per Lord Griffiths.

105 At 857 per Lord Griffiths.

106 Spencer on Byron, above n 2, at [209]-[212].

107 At [207].

108 Ministry of Health v Atkinson [2012] NZCA 184, [2012] 3 NZLR 456 at [60]. 
scope of the claimed duty of care and those outside it based on the alleged grounds of vulnerability (an ability to obtain insurance, for example). If the vulnerable class could protect itself in ways that the self-sufficient comparator could, then it would not be vulnerable, and if members of the vulnerable class could protect themselves then the claimed duty would be owed to an overly broad class.

To illustrate this, it is helpful to consider the grounds upon which Asher J considered the plaintiffs in the Carter Holt case were arguably vulnerable. ${ }^{109}$ The first ground (latent nature of the defects), clearly justifies a finding of vulnerability. It is unreasonable to expect a plaintiff to prevent damage they cannot know is occurring, and such damage is different from damage that is detectable by a layperson and that which they can take steps to prevent or mitigate. ${ }^{110}$ The second and third grounds (reasonableness of contracting and availability of insurance) also support a finding of vulnerability. It is unreasonable for the plaintiffs to have to contract with a wide variety of different manufacturers of different and specific goods to protect themselves as compared to a party who had a direct relationship with a manufacturer or was dealing with a small number of potential contracts. Similarly, if there was no insurance available against the resulting loss to the plaintiffs, then they are clearly disadvantaged as against a comparator party who could insure against a claimed loss.

It is true that comparator groups have been criticised strongly in the human rights context. ${ }^{111}$ Those criticisms are less apposite within the negligence context however. Comparator groups affect the legal analysis in discrimination cases, but here the effect they have is helpful. ${ }^{112}$ The definition of the vulnerable class likely defines the scope of persons to whom a claimed duty of care is owed, and on that basis engaging in a clear comparator exercise ensures a workable and consistent duty of care is developed. Such concerns are less relevant in the human rights context because the class of claimants affected by a ruling is specified. ${ }^{113}$ Here too concerns about arbitrary and early dismissal of just claims are less relevant, as there are other areas within the duty of care analysis a claimant can succeed on. ${ }^{114}$ In fact, courts that engage in a thorough comparative analysis are unlikely to make the kind of problematic presumptions that dismissed just claims in Te Mata. ${ }^{115}$ It is true that such measures may not be necessary, but given the fundamental need to ensure clarity of analysis it is suggested they be adopted.

109 Carter Holt (HC), above n 7, at [46].

110 Carter Holt (CA), above n 3, at [49] and [74].

111 Asher Emanuel "To whom will ye liken Me, and make Me equal? Reformulating the Role of the Comparator in the Identification of Discrimination" (2014) 45 VUWLR 1.

112 At 6 .

113 Bill of Rights Act 1990, s 19; and Human Rights Act 1993, s 21.

114 Emanuel, above n 111, at 7.

115 Te Mata, above n 43. 


\section{CONCLUSION}

Given the utility and history of vulnerability in the law of negligence, it might be thought unfortunate that the comments in Spencer on Byron cast so much uncertainty on its usage. That uncertainty need not remain, however, because the approach taken by the High Court in the Carter Holt case is capable of responding to its critics. The approach to vulnerability in New Zealand ought to be a straightforward application of the Woolcock test, as Asher J undertook in that case. With respect, it is the addition of alternative tests or misapplications of that test that are the likely source of any conceptual confusion, a problem the Court of Appeal in the Carter Holt case contributed to. Clarity of the law is a laudable and crucial aim, but there is no reason to believe that the Woolcock test need be anything other than straightforward. Indeed, vulnerability is capable of sitting comfortably alongside major concepts associated with the duty of care and providing useful assistance to courts assessing the validity of a claimed novel duty.

The strength of the New Zealand approach to negligence is its ability to take a holistic and flexible approach to the challenges presented by novel duties of care. This is necessary because of the wide variety of situations the law of negligence must confront. Yet if concepts like vulnerability are confused or excluded from the analysis, the court risks limiting the broad array of tools it needs to deal with the different challenges presented by the tort. So long as a concept is useful and clear, its potential to assist in a given claim means it should be left at the court's disposal. Vulnerability is capable of assisting courts to that end, and acknowledging that will ensure that the law of negligence provides clear and just results. 
(2016) 47 VUWLR 